\title{
Brain Region Specific Alterations in the Protein and mRNA Levels of Protein Kinase A Subunits in the Post-Mortem Brain of Teenage Suicide Victims
}

\author{
Ghanshyam N Pandey*,', Yogesh Dwivedi', Xinguo Ren', Hooriyah S Rizavi', Amal C Mondal', \\ Pradeep K Shukla' and Robert R Conley ${ }^{2}$ \\ 'Department of Psychiatry, The Psychiatric Institute, University of Illinois at Chicago, Chicago, IL, USA; ${ }^{2}$ Maryland Psychiatric Research Center, \\ Baltimore, MD, USA
}

\begin{abstract}
Protein kinase A (PKA), a critical component of the adenylyl cyclase signaling system, phosphorylates crucial proteins and has been implicated in the pathophysiology of depression and suicide. The objective of the study was to examine if changes in PKA activity or in the protein and messenger RNA (mRNA) expression of any of its subunits are related to the pathophysiology of teenage suicide. We determined PKA activity and the protein and mRNA expression of different subunits of PKA in cytosol and membrane fractions obtained from the prefrontal cortex, (PFC) hippocampus, and nucleus accumbens (NA) of post-mortem brain from 17 teenage suicide victims and 17 nonpsychiatric control subjects. PKA activity was significantly decreased in the PFC but not the hippocampus of teenage suicide victims as compared with controls. However, the protein and mRNA expression of only two PKA subunits, that is, PKA RI $\alpha$ and PKA RI $\beta$, but not any other subunits were significantly decreased in both membrane and cytosol fractions of the PFC and protein expression of RI $\alpha$ and RI $\beta$ in the NA of teenage suicide victims as compared to controls. A decrease in protein and mRNA expression of two specific PKA subunits may be associated with the pathogenesis of teenage suicide, and this decrease may be brain region specific, which may be related to the specific behavioral functions associated with these brain areas. Whether these changes in PKA subunits are related to suicidal behavior or are a result of suicide or are specific to suicide is not clear at this point.

Neuropsychopharmacology (2005) 30, I548-1556, advance online publication, 25 May 2005; doi: I 0. I038/sj.npp. 1300765
\end{abstract}

Keywords: PKA; suicide; post mortem; teenage; mRNA; immunolabeling

\section{INTRODUCTION}

Abnormalities in the phosphoinositide (PI) and the adenylyl cyclase (AC) signal transduction systems have been implicated in the pathophysiology of suicide. For example, it has been shown by several investigators that serotonin ${ }_{2 \mathrm{~A}}$ receptors $\left(5 \mathrm{HT}_{2 \mathrm{~A}}\right)$ and these receptor-linked components of the PI signaling system are altered in post-mortem brain of suicide victims (Gross-Isseroff et al, 1998; Pandey et al, 1999, 2002, 2004). Similarly, some studies indicate abnormalities of $\beta$-adrenergic receptors and these receptor-linked components of the AC signaling system in post-mortem brain of suicide victims (Pacheco et al, 1996; Dwivedi et al, 2002a, b, 2004). Whereas there is some understanding of the

*Correspondence: Professor GN Pandey, The Psychiatric Institute, University of Illinois at Chicago, 160I West Taylor Street, Chicago, IL 606/2, USA, Tel: + I 312 4I3 4540, Fax: + I 312413 4547,

E-mail: Gnpandey@psych.uic.edu

Received 7 December 2004; revised 25 March 2005; accepted 28 March 2005

Online publication: II April 2005 at http://www.acnp.org/citations/ Npp04 I I 05040573/default.pdf neurobiology of adult suicide, the neurobiology of teenage (adolescent) suicide is not very well understood. The characteristics and the risk factors for teenage suicide may be similar to those of adult suicide in some respects but are different in others. Teenage suicide is driven primarily by impulsive aggressive behavior and is also prone to stress and other environmental factors (Apter et al, 1995; Brent et al, 1993). Protein phosphorylation of neurotransmitter receptors, transcription factors, and other proteins mediated by kinases is a primary mechanism for the regulation of neurotransmitter function, such as inactivation of neurotransmitter receptors causing their downregulation or desensitization, release of neurotransmitters, modulation of transcription factors, and activation and therefore regulation of gene expression (Nestler and Greengard, 1994). Protein phosphorylation mechanisms may thus play a major role in the physiological functions of the central nervous system (CNS).

Protein kinase A (PKA) is one of the major phosphorylating enzymes and is a key component of the cyclic AMP (cAMP) signaling system, since the biologically relevant 
effects of cAMP that occur as a result of the activation of many $G$ protein-coupled receptors are mediated by the activation of PKA (Fimia and Sassone-Corsi, 2001). In the absence of CAMP, the PKA holoenzyme exists as an inactive tetramer composed of two catalytic subunits bound to a regulatory subunit dimer. On the basis of elution patterns, two different PKA isozymes, known as PKA I and PKA II, have been identified. These two isozymes have been shown to be comprised of two different $\mathrm{R}$ subunits, known as RI and RII, which are further comprised of subunits, known as $\mathrm{RI} \alpha$ and $\mathrm{RI} \beta$, and $\mathrm{RII} \alpha$ and $\mathrm{RII} \beta$. In addition, three catalytic subunits, known as $\mathrm{C} \alpha, \mathrm{C} \beta$, and $\mathrm{C} \gamma$, have also been identified. Each $\mathrm{R}$ subunit has two cAMP binding sites, and on activation and binding with cAMP, each $\mathrm{R}$ subunit dissociates into a dimeric $\mathrm{R}$ subunit complex and two monomeric active $\mathrm{C}$ subunits (Skålhegg and Tasken, 2000).

Very recently, we observed that the activity and the protein and messenger RNA (mRNA) expression of one of the phosphorylating enzyme, protein kinase $\mathrm{C}$ (PKC), a component of the PI signaling system, are decreased in the prefrontal cortex (PFC) and hippocampus of teenage suicide victims (Pandey et al, 2004). It is therefore important to examine if there also exist abnormalities in other phosphorylating enzyme, PKA, in teenage suicide victims, especially since it has been reported that activation of PKC modulates mRNA for specific subunits of PKA (Tasken et al, 1991). Our group recently reported a decrease in $\left[{ }^{3} \mathrm{H}\right]$ cAMP binding as well as in PKA activity in the PFC of adult depressed suicide victims (Dwivedi et al, 2002a), and a decrease in the protein and mRNA expression of selective subunits of PKA in the PFC of adult depressed suicide victims (Dwivedi et al, 2004). It is therefore also important to determine if there are differences in PKA between the teenage and adult suicide victims since there appear to be differences in the characteristics and risk factors of teenage suicide victims compared with adult subjects. In the present study, we have therefore determined PKA activity, cAMP binding sites, as well as the protein and mRNA expression of PKA subunits in the PFC, hippocampus, and nucleus accumbens (NA) of post-mortem brain samples of teenage suicide victims and matched nonpsychiatric control subjects.

\section{MATERIALS AND METHODS}

\section{Subjects}

Right hemisphere of the PFC (Brodmann's area (BA) 9), hippocampus, and NA (from 17 teenage suicide victims and 17 nonpsychiatric teenage control subjects, hereafter referred to as control subjects) obtained from the Brain Collection Program of the Maryland Psychiatric Research Center, Baltimore, MD, in collaboration with the Medical Examiner's Office of the State of Maryland, were used. The whole hippocampus and NA were dissected, chopped into small pieces, and stored at $-80^{\circ} \mathrm{C}$. Brain samples were free of any neuropathological abnormalities or HIV antibodies. Toxicological data were obtained by analysis of urine and blood samples from these subjects.

The diagnosis of suicide victims and control subjects in the study were based on the Diagnostic Evaluation After
Death (DEAD) and the Structured Clinical Interviews for the DSM-III-R (SCID) as described earlier (Pandey et al, 2004). Controls were verified as free from mental illness or substance abuse. The protocols for tissue sampling and retrospective assessments were approved by the Institutional Review Board (IRB) of the University of Maryland. All the biochemical determinations were made in blinded fashion.

\section{Determination of $B_{\max }$ and $K_{\mathrm{D}}$ of $\left[{ }^{3} \mathrm{H}\right] \mathrm{cAMP}$ Binding}

Specific $\left[{ }^{3} \mathrm{H}\right]$ cAMP binding was performed as previously described (Dwivedi et al, 2002a) Brain samples were homogenized in 10 volumes of ice-cold buffer containing $20 \mathrm{mM}$ of Tris- $\mathrm{HCl}\left(\mathrm{pH} 7.4\right.$ at $\left.25^{\circ} \mathrm{C}\right), 2 \mathrm{mM}$ of ethylenediaminetetraacetic acid (EDTA), $25 \mathrm{mM}$ of 2 -mercaptoethanol,4-(2-aminoethyl) benzenesulfonyl fluoride, and $10 \mu \mathrm{g} /$ $\mathrm{ml}$ of leupeptin. The homogenate was centrifuged at $100000 \mathrm{~g}$ for $60 \mathrm{~min}$. The supernatant (S1) was saved. The pellet was resuspended in the same buffer and centrifuged again at $100000 \mathrm{~g}$ for $60 \mathrm{~min}$. This supernatant (S2) was combined with $\mathrm{S} 1$ and used as the cytosol fraction; the pellet was homogenized in the same buffer and used as the membrane fraction. The protein content was determined in these two fractions according to the procedure of Lowry et al (1951) by using bovine serum albumin as the standard. $\left[{ }^{3} \mathrm{H}\right]$ cAMP binding was performed in triplicate in an incubation buffer containing $20 \mathrm{mM}$ of phosphate buffer $\left(\mathrm{pH} 7.4\right.$ at $\left.25^{\circ} \mathrm{C}\right), 2 \mathrm{mM}$ of EDTA, and $15 \mathrm{mM}$ of $2-$ mercaptoethanol (PEM buffer); [ $\left.{ }^{3} \mathrm{H}\right]$ cAMP $(0.25-10 \mathrm{nM})$; membrane or cytosol fraction ( $\sim 25 \mu \mathrm{g}$ protein); $0.25 \mathrm{mg}$ of bovine serum albumin; and $1.5 \mathrm{mM} 3$-isobutyl-1-methylyxanthine in a total volume of $500 \mu \mathrm{l}$. The incubation was carried out at $25^{\circ} \mathrm{C}$ for $60 \mathrm{~min}$ and terminated by rapid filtration under vacuum by using a Brandel Cell Harvester (Biomedical Research and Development Laboratories Inc., Gaithersburg, MD) followed by three washes with $2 \mathrm{ml}$ of cold PEM buffer. The radioactivity retained on the filter was counted by using a liquid scintillation counter. Nonspecific binding was defined as the radioactivity bound in the presence of $5 \mu \mathrm{M}$ cAMP. $B_{\max }$ and $K_{\mathrm{D}}$ were calculated by the Scatchard plots by using the EBDA program (McPherson, 1985).

\section{Determination of PKA Activity}

Basal and CAMP-stimulated PKA activity were determined in the membrane and cytosol fractions as reported previously (Dwivedi et al, 2002a). This procedure is based on the phosphorylation of a specific substrate, kemptide (Leu-Arg-Arg-Ala-Ser-Leu-Gly), which uses the transfer of [gamma]-phosphate of $(\gamma-32 \mathrm{P})$ ATP by PKA. PKA activity was determined in the presence and the absence of $100 \mu \mathrm{M}$ cAMP. The phosphorylated substrate was separated from residual $(\gamma-32 \mathrm{P})$ ATP by spotting $20 \mu \mathrm{l}$ of reaction mixture onto p81 phosphocellulose paper, washing with $75 \mathrm{mM} \mathrm{H}_{3} \mathrm{PO}_{4}$, and finally with acetone. Data are expressed as picomoles of $32 \mathrm{P}$ phosphate transferred to kemptide substrate/min/mg protein. 


\section{Quantitation of Catalytic and Regulatory Subunit Isoforms of PKA by Western Blot}

Immunolabeling of individual catalytic and regulatory subunits of PKA in membrane and cytosol fractions was determined by Western blot (Dwivedi et al, 2004). Equal volumes of membrane or cytosol fractions $(20 \mu \mathrm{l}$ containing $15 \mu \mathrm{g}$ protein) were resolved onto $10 \%(\mathrm{w} / \mathrm{v})$ SDS-polyacrylamide gel and blotted on enhanced chemiluminescence (ECL) membrane (Amersham, Arlington Heights, IL). Membranes were incubated with polyclonal antibodies for PKA $\mathrm{RI} \alpha, \mathrm{RI} \beta, \mathrm{RII} \alpha, \mathrm{RII} \beta, \mathrm{C} \alpha$, or $\mathrm{C} \beta$ (Santa Cruz Biotechnology, Santa Cruz, CA) overnight at $4{ }^{\circ} \mathrm{C}$. The dilution for each antibody was as follows: $\operatorname{PKA} \operatorname{RI} \alpha, \operatorname{RI} \beta$ (1:2500); $\operatorname{RII} \alpha, \operatorname{RII} \beta$ (1:2000); and $\mathrm{C} \alpha, \mathrm{C} \beta$ (1:5000) and exposed to ECL autoradiography film. The same membranes were stripped and reprobed with $\beta$-actin (Sigma Chemical Co., St Louis, MO), which was used as a housekeeping protein. The optical densities (O.D.) of the bands were quantified using the Loats Image Analysis System (Westminster, MD), and the O.D. of each band was corrected by the O.D. of the corresponding $\beta$-actin band.

\section{Determination of mRNA Levels of PKA Subunits by Quantitative RT-PCR}

The detailed procedures for determining mRNA levels of various PKA isozymes by quantitative RT-PCR are described in our earlier publications (Dwivedi et al, 2002b, 2004). Total RNA was isolated by $\mathrm{CsCl}_{2}$ ultracentrifugation. The degradation of each mRNA was checked by evaluating the sharpness of 28 and $18 \mathrm{~S}$ rRNA. None of the samples used in this study showed any significant degeneration.

mRNA levels were quantitated using internal standards as described earlier (Dwivedi et al, 2004). The primer pairs were designed to allow amplification of bp: forward, 5 -TAC AAG CTT GGA AGC ACA CTG AGA AAG CGG, and reverse, 5'-TAC GGA TCC GCT TAA CGC ACT TCA AGG GGC (GenBank accession \#M33336) for RI $\alpha$; forward, 5' TAC AAG CTT GAT GTA CAA CAC CCC GAG AGC, and reverse, 5'-TAC GAA TTC ATG GCA GCG GGC AAT CTC GAC for RII $\alpha$ (GenBank accession \#NM_004157); forward, 5'-TAC AAG CTT GTC AAA CTC ACA GTC GGA CTC, and reverse, 5'-TAC GAA TTC TCC GTT CAC GTA CAC ATC CAC (GenBank accession \#M65066) for $\mathrm{RI} \beta$. Internal standard templates were generated by site-directed mutagenesis to introduce an XhoI restriction site. The internal standard sequences were as follows: forward, $5^{\prime}$-CTT CAT TAT TCT CGA GGG GTC AGC TG for RI $\alpha$; forward, $5^{\prime}$-AGG TGT CAG CTC GAG TGA AGA TTG for RII $\alpha$; forward, 5' CTG GCC AAG GAG ATC TCC AAG AAC G for RI $\beta$. To quantitate mRNA levels, decreasing concentrations of PKA internal standard cRNA were added to $1 \mu \mathrm{g}$ of total RNA and reverse transcribed. After termination of the RT reaction, cDNA aliquots containing reverse-transcribed material were amplified for 26 cycles with Hot Tub DNA polymerase. Trace amounts of $\left[{ }^{32} \mathrm{P}\right] \mathrm{dCTP}(0.5-1 \mu \mathrm{Ci} / \mathrm{sam}-$ ple) were included during the PCR step for subsequent quantification. Following amplification, aliquots were digested with $X h o I$ in triplicate and run by $1.5 \%$ agarose gel electrophoresis.
To quantitate the amount of product corresponding to the reverse-transcribed and amplified mRNA, the ethidium bromide-stained bands were excised and counted. The results were calculated as the counts incorporated into the amplified cRNA standard divided by the counts incorporated into the corresponding subunit mRNA amplification product $v s$ a known amount of internal standard cRNA added to the test sample. The results are expressed as attomoles mRNA/ $\mu$ g total RNA.

\section{Statistical Analysis}

Data analyses were performed using the SPSS 8.0 (Chicago, IL) statistical software package. All values reported are mean \pm the standard deviation (SD) The differences in PKA catalytic activity, mRNA and protein levels of PKA isozymes, age, $\mathrm{PMI}$, and $\mathrm{pH}$ of the brain between suicide victims and control subjects were analyzed using the independent sample $t$-test. The relationship between PKA catalytic activity, mRNA and protein levels of PKA isozymes PMI, age, gender, and $\mathrm{pH}$ of the brain were determined by Pearson's product-moment correlation analysis. The statistical differences between subgroups of suicide victims (with and without mental disorders) and controls were evaluated by one-way analysis of variance (ANOVA), followed by post hoc analysis. Bonferroni's corrected $P$-values were reported.

\section{RESULTS}

The detailed demographic characteristics of the teenage suicide victims $(n=17)$ and the control subjects $(n=17)$ are given in Table 1 . There were no significant differences in age, $\mathrm{PMI}$, or $\mathrm{pH}$ of the brain samples between controls and suicide victims. There were 13 subjects who died of violent death in the suicide group and 16 in the control group. The number of nonviolent deaths was therefore relatively small in both groups and hence the effect of violence on any of the measures was not determined. Since the majority of cases in both groups died by violent death, the effect of the mode of death, if any, was similar in both groups.

\section{$B_{\max }$ and $K_{\mathrm{D}}$ of cAMP Binding}

$B_{\max }$ and $K_{\mathrm{D}}$ of $\left[{ }^{3} \mathrm{H}\right] \mathrm{cAMP}$ were determined in both membrane and cytosol fractions. $B_{\max }$ of $\left[{ }^{3} \mathrm{H}\right] \mathrm{cAMP}$ binding was found to be decreased in both membrane and cytosol fractions of PFC of suicide subjects as compared with control subjects (Figure 1). No significant differences were observed in $K_{\mathrm{D}}$ values in either the membrane or the cytosol fractions between suicide and control subjects.

\section{PKA Activity}

PKA activity was determined in membrane and cytosol fractions in the presence of cAMP in PFC and hippocampus of teenage suicide victims and control subjects. We found a significant decrease in cAMP-stimulated PKA activity in both cytosol and membrane fractions of PFC of teenage suicide victims as compared with control subjects, as shown in Figure 2. No significant difference in the PKA activity between suicide victims and controls was observed in membrane or cytosol fractions of the hippocampus. 
Table I Demographic Characteristics of Teenage Suicide and Normal Control Subjects

\begin{tabular}{|c|c|c|c|c|c|c|c|c|}
\hline $\begin{array}{l}\text { Group and } \\
\text { subject }\end{array}$ & Age & Sex & Race & PMI & pH & Diagnosis & Drug toxicity & $\begin{array}{l}\text { Cause of } \\
\text { death }\end{array}$ \\
\hline \multicolumn{9}{|l|}{ Control } \\
\hline 2 & 13 & Male & White & NA & 5.19 & Control & - & Accident \\
\hline 3 & 16 & Male & Black & 6 & 6.54 & Control & - & GSW \\
\hline 4 & 19 & Male & Black & 9 & 6.85 & Control & - & GSW \\
\hline 6 & 18 & Male & White & 8 & 6.7 & Control & - & Stabbing \\
\hline 7 & 19 & Male & Black & 12 & 5.9 & Control & - & GSW \\
\hline 8 & 17 & Male & Black & 11 & 6.52 & Control & - & GSW \\
\hline 9 & 16 & Male & White & 10 & 5.42 & Control & - & Stabbing \\
\hline 10 & 18 & Male & Black & II & 6.16 & Control & - & GSW \\
\hline 15 & 16 & Male & White & 21 & 5.97 & Control & - & Hanging \\
\hline 16 & 17 & Female & Black & 26 & 6.23 & Control & - & $\begin{array}{l}\text { Multiple } \\
\text { injuries }\end{array}$ \\
\hline 17 & 18 & Male & White & 19 & 6 & Control & - & Drowning \\
\hline Mean & $|6.7|$ & $\begin{array}{l}\text { I6 Male } \\
\text { I Female }\end{array}$ & $\begin{array}{l}5 \text { White } \\
12 \text { Black }\end{array}$ & 13.97 & 6.04 & & & \\
\hline SD & 1.93 & & & 7.1 & 0.41 & & & \\
\hline \multicolumn{9}{|l|}{ Suicide } \\
\hline 23 & 17 & Male & White & 11 & 5.9 & No mental disorder & None & GSW \\
\hline 24 & 16 & Male & Black & 12 & 5.4 & No mental disorder & None & Drug overdose \\
\hline 25 & 13 & Male & White & 18 & 6 & Hyperactive and attention deficit & Ritalin & Hanging \\
\hline 26 & 13 & Male & Black & 11 & 5.37 & No mental disorder & None & Hanging \\
\hline 27 & 15 & Male & White & 11 & 5.33 & Major depression & None & Asphyxia \\
\hline 28 & 15 & Female & White & 17 & 5.58 & $\begin{array}{l}\text { Major depression and hyperactive } \\
\text { and attention deficit }\end{array}$ & Imipramine, desipramine & Drug overdose \\
\hline 29 & 16 & Male & Other & 20 & 6.17 & No mental disorder & None & Hanging \\
\hline 30 & 17 & Female & White & 25 & 5.55 & Adjustment disorder & Verapamil & Drug overdose \\
\hline 31 & 15 & Male & White & 27 & 6.08 & $\begin{array}{l}\text { Adjustment disorder and major } \\
\text { depression }\end{array}$ & $\begin{array}{l}\text { Pseudoephedrine, } \\
\text { phenylpropanolamine }\end{array}$ & GSW \\
\hline 32 & 16 & Female & White & 18 & 6.31 & No mental disorder & Amitriptyline & GSW \\
\hline 33 & 16 & Female & White & 33 & 6.61 & Adjustment disorder & None & GSW \\
\hline 34 & 16 & Male & White & 24 & 6.81 & Adjustment and conduct disorder & None & Hanging \\
\hline Mean & 15.65 & $\begin{array}{l}10 \text { Male } \\
7 \text { Female }\end{array}$ & $\begin{array}{l}13 \text { White } \\
3 \text { Black }\end{array}$ & 16.12 & 5.96 & & & \\
\hline SD & 1.99 & & & 7.54 & 0.47 & & & \\
\hline
\end{tabular}

GSW, gunshot wound; NA, not available; PMI, post-mortem interval. 


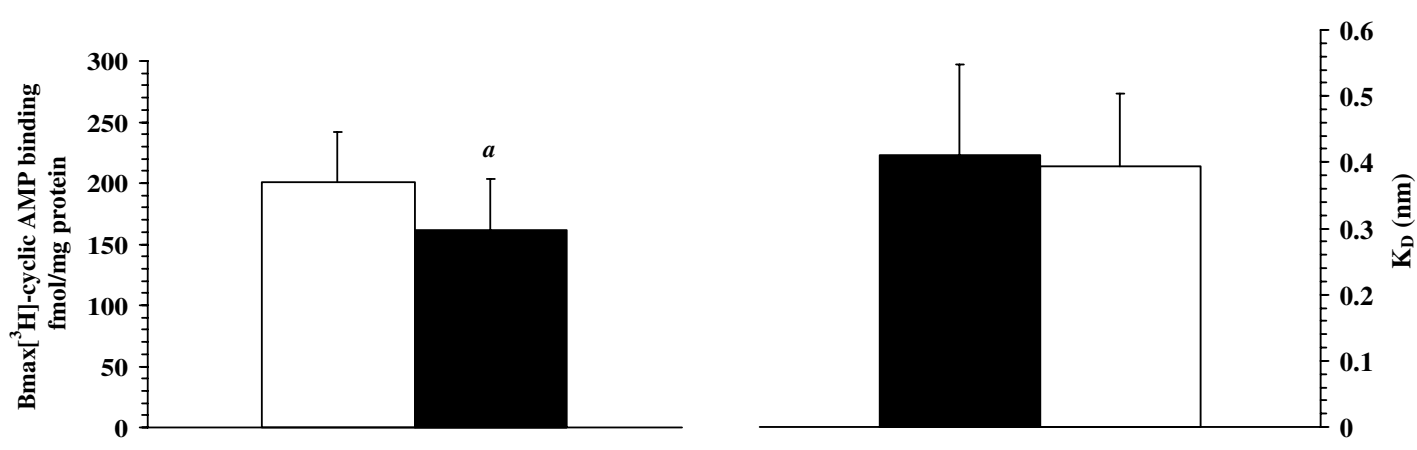

Membrane
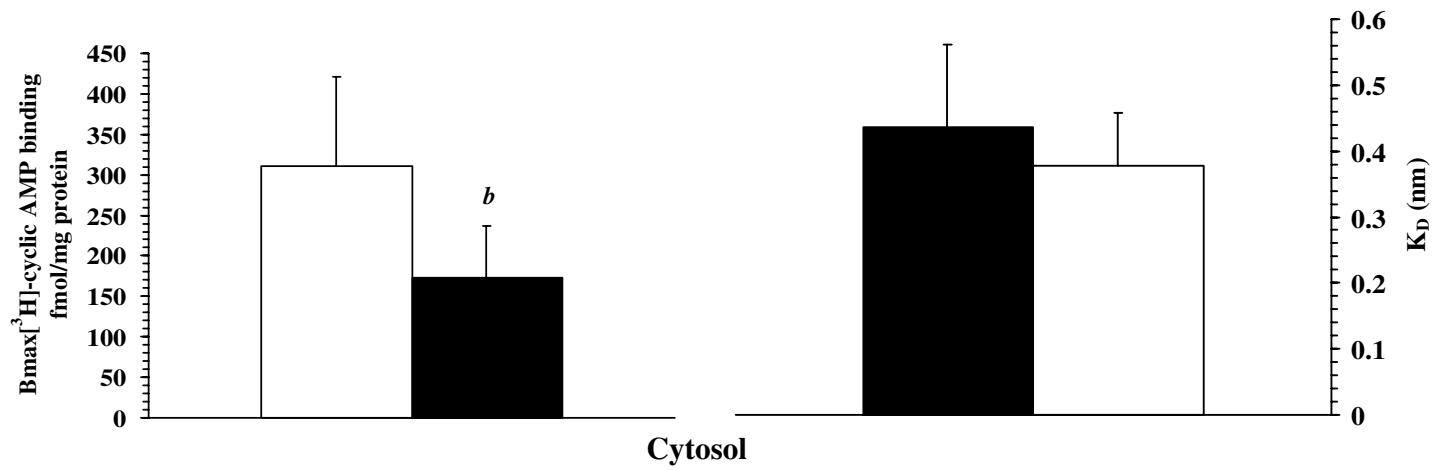

Figure I $\quad\left[{ }^{3} \mathrm{H}\right] \mathrm{cAMP}$ binding $\left(B_{\max }\right)$ in membrane and cytosol fraction in PFC of suicide victims $(n=17 ; \boldsymbol{\square})$ and control subjects $(n=17 ; \square)$. Values are the mean $\pm S D{ }^{a} p<0.005,{ }^{b} p<0.001$.
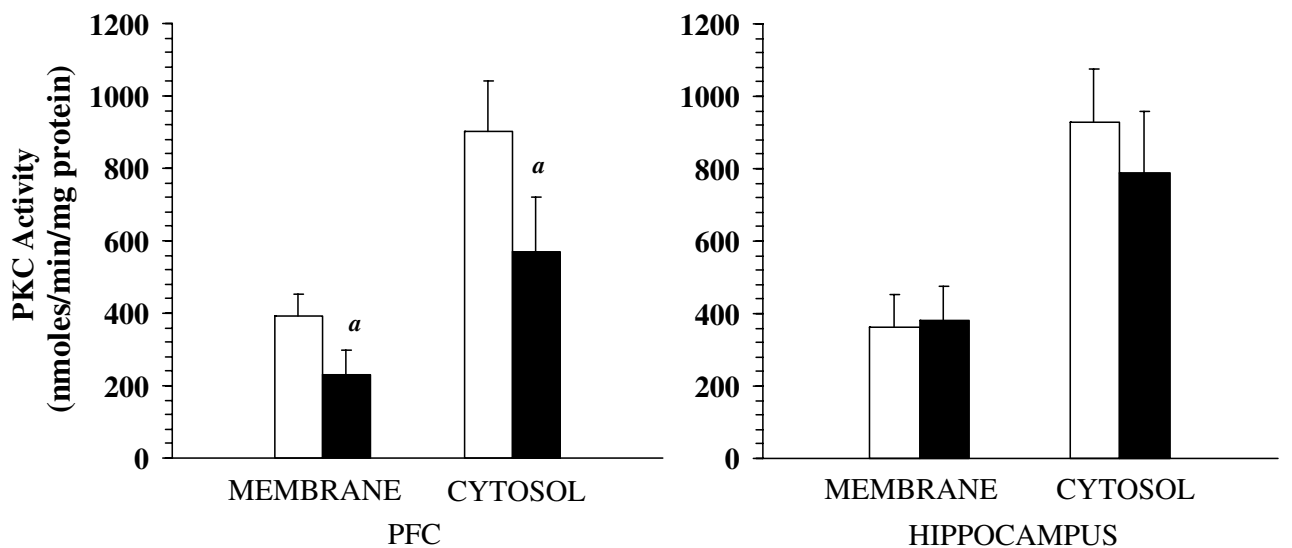

Figure 2 PKA catalytic activity in membrane and cytosol fractions of the PFC and hippocampus obtained from suicide victims ( $n=17$; $\mathbf{\square})$ and control subjects $(n=17 ; \square)$. Values are the mean \pm SD ${ }^{a} p<0.001$.

\section{Immunolabeling of PKA Subunits in PFC, Hippocampus, and NA of Suicide Victims and Control Subjects}

We determined the immunolabeling of PKA RI $\alpha$, RII $\alpha, \operatorname{RI} \beta$, $\operatorname{RII} \beta, \mathrm{C} \alpha$, and $\mathrm{C} \beta$ subunits in membrane and cytosol fractions of PFC in suicide victims and control subjects. $\beta$-Actin was used as housekeeping protein. We did not find any significant change in the levels of $\beta$-actin in any of the brain areas between suicide victim and control subjects. Therefore, ratios of PKA subunits with $\beta$-actin were calculated. A representative Western blot demonstrating the immunolabeling of different PKA subunits is shown in Figure 3. Analysis of the immunolabeling data, as shown in Figure 4 , indicates that the protein expression of the RI $\alpha$ and $\operatorname{RI} \beta$ subunits was significantly decreased in both the membrane as well as the cytosol fractions of PFC in the suicide subjects as compared with control subjects. No significant differences were observed in the immunolabeling of other PKA subunits either in membrane or cytosol (data not shown). To examine if this selective decrease in PKA subunits is region specific, we determined the immunolabeling of PKA subunits in the hippocampus as well as NA of suicide victims and control subjects. We observed no significant differences in $\mathrm{RI} \alpha$ and $\mathrm{RI} \beta$ subunits, the two subunits that were decreased in the PFC, either in the membrane or the cytosol fractions obtained from the hippocampus (Figure 4). On the other hand, selective changes in PKA subunits were evident in the NA. Similarly as in the PFC, the protein expression level of $\mathrm{RI} \alpha$ and $\mathrm{RI} \beta$ 
was significantly decreased in both membrane and cytosol fractions obtained from NA of suicide victims as compared with control subjects (Figure 4).

The immunolabeling results of PKA subunits in the PFC, hippocampus, and NA thus indicate a significant decrease

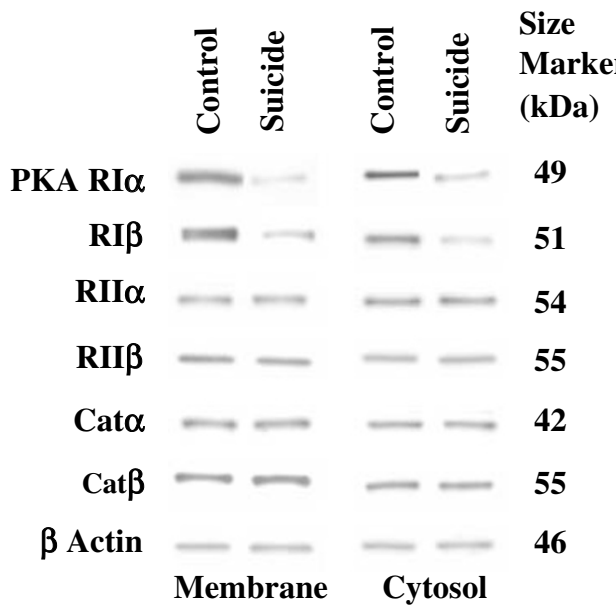

Figure 3 Representative Western blots showing the immunolabeling of PKA isozymes in membrane and cytosol fractions from the PFC of one control subject and one suicide victim. Protein samples were subjected to 10\% polyacrylamide gel electrophoresis and transferred to ECL-nitrocellulose membranes, which were then incubated with primary antibodies specific for each PKA isozymes secondary anti-rabbit antibody. The membranes were striped and probed with $\beta$-actin primary and anti-mouse secondary antibody. The bands were quantified as described under Materials and Methods. Ratio of the O.D. of PKA isozymes to that of $\beta$ actin was calculated. in $\mathrm{RI} \alpha$ and $\mathrm{RI} \beta$ subunits, both in the PFC and NA of suicide victims as compared with control subjects, but no significant differences in any of the subunits in the hippocampus.

\section{mRNA Levels of PKA Subunits in PFC of Suicide Victims and Control Subjects}

To examine whether the decreases in specific PKA subunits are related to altered transcription of their respective mRNAs, we determined the mRNA levels of those PKA subunits that we found to be significantly decreased in the PFC and NA of suicide victims. The mRNA levels of specific PKA subunits were determined using a quantitative RTPCR. The results of a quantitative RT-PCR analysis for PKA $\mathrm{RI} \alpha$ and $\mathrm{RI} \beta$ in the PFC, hippocampus, and NA are shown in Figure 5. Similarly as with protein expression levels, the mRNA levels of PKA RI $\alpha$ and RI $\beta$ were significantly decreased in the PFC of suicide victims as compared with control subjects. On the other hand, there were no significant changes in mRNA expression levels of PKA $\mathrm{RI} \alpha$ or PKA RI $\beta$ in the hippocampus of teenage suicide victims as compared with control subjects. When we determined the mRNA levels of PKA RI $\alpha$ and RI $\beta$ subunits in the NA, we found a significant decrease in the mRNA levels of PKA RI $\alpha$, but not PKA RI $\beta$ in suicide victims as compared to normal controls, as seen in Figure 5.

\section{Effects of Confounding Variables and Diagnosis}

To determine whether confounding variables may affect the various measures of PKA, we examined the relationships
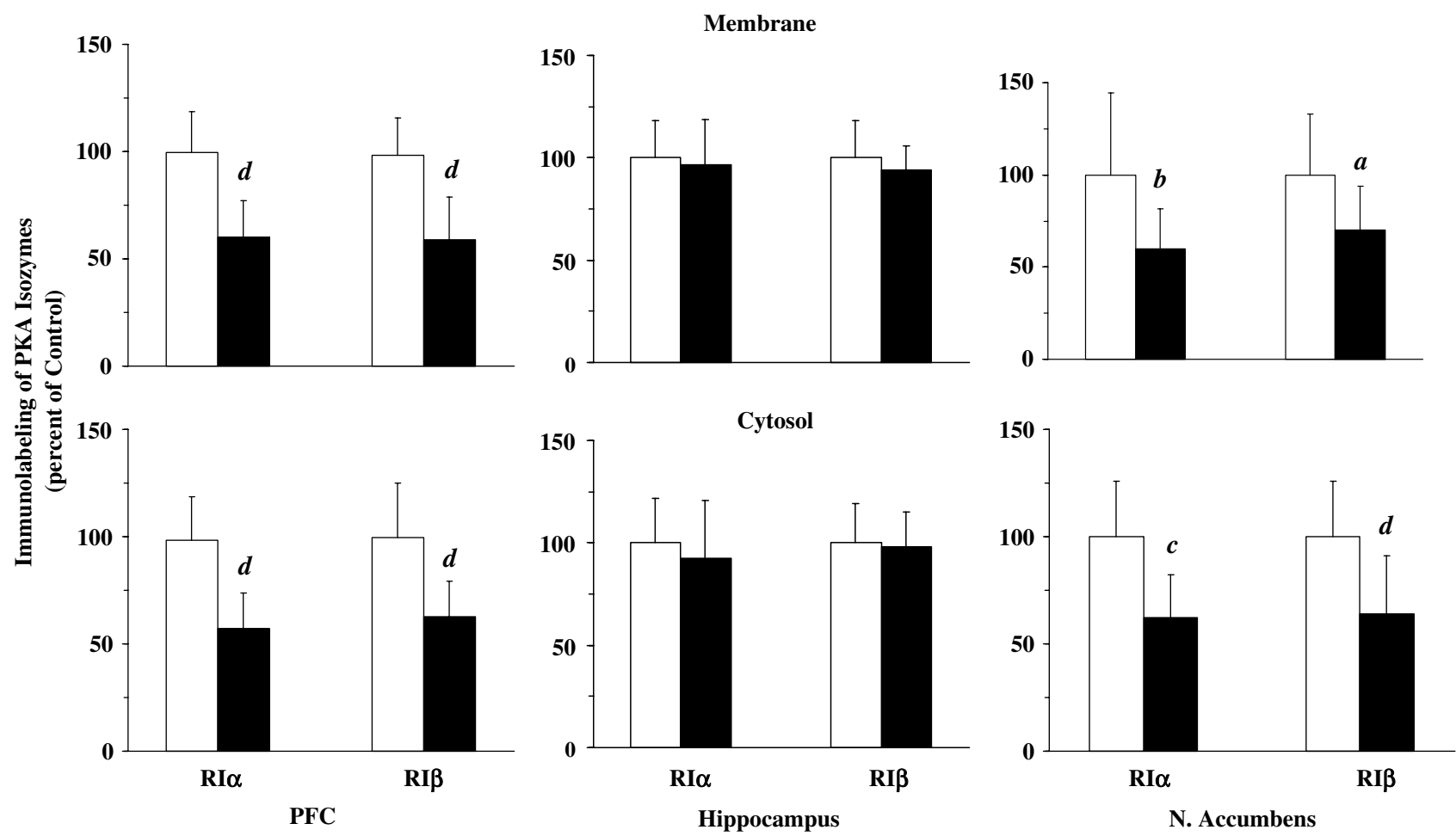

Figure 4 Protein levels of PKA isozymes in membrane and cytosol fractions of the PFC, hippocampus, and NA obtained from suicide victims ( $n=17$; and control subjects $(n=17 ; \square)$. Values are the mean $\pm S D{ }^{a} p<0.008,{ }^{b} p<0.004,{ }^{c} p<0.002,{ }^{d} p<0.001$. 

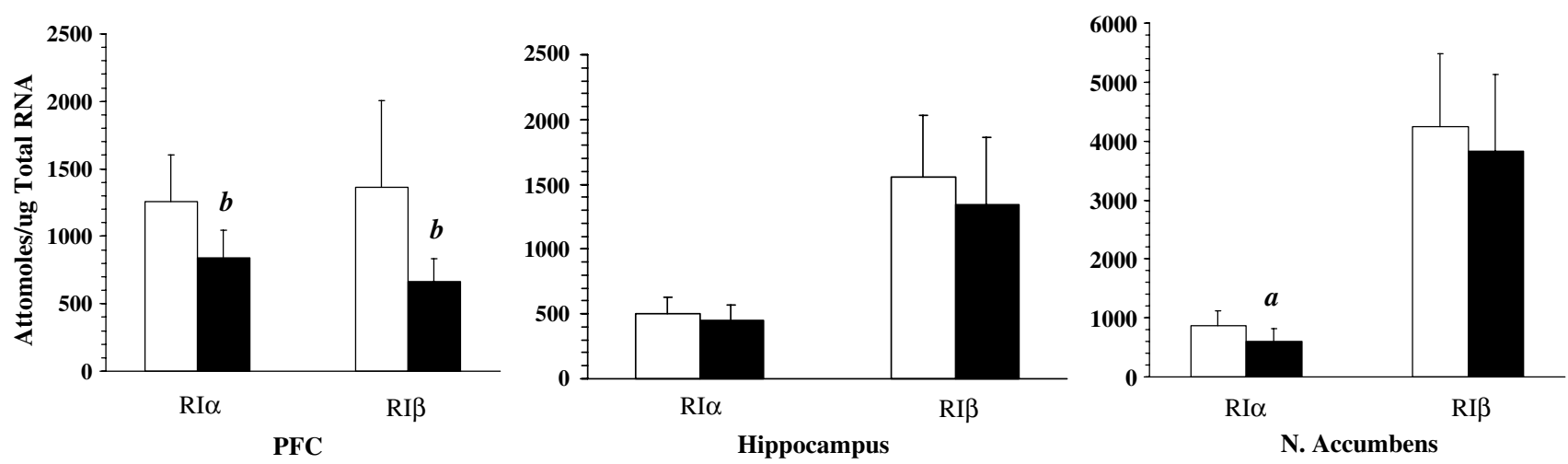

Figure 5 mRNA levels of PKA Rl $\alpha$ and RI $\beta$ in the PFC (control, $n=17$; suicide, $n=17$ ), hippocampus (control, $n=15$; suicide, $n=15$ ), and NA (control, $n=15$; suicide, $n=15$ ) of suicide victims

between age, PMI, and $\mathrm{pH}$ of the brain and catalytic activity and mRNA and protein levels of PKA isozymes. We did not find any effects of these confounding variables on any of the PKA measures, either in the PFC or hippocampus (data not shown). In order to examine if changes in PKA were related to the presence of mental disorders or were specific to suicide, we compared PKA activity and protein and mRNA expression, and found that there were no significant differences between subjects with mental disorders $(n=9)$ and subjects with no history of mental disorders $(n=8)$ in catalytic activity of PKA or protein and mRNA expression of any of the PKA subunits either in the membrane or in the cytosol fractions. However, both groups were significantly lower than control subjects in terms of protein and mRNA expression of the various PKA isozymes (data not shown). These results thus suggest that the decreases in protein and mRNA expression of PKA isozymes found in teenage suicide victims are independent of diagnosis.

\section{DISCUSSION}

This is the first study to show a brain region-specific alteration in PKA activity in teenage suicide victims. We also determined that this decrease in PKA activity and in cAMP binding to PKA was associated with a decrease in specific subunits of PKA, that is, RI $\alpha$ and RI $\beta$ subunits, in the PFC of suicide victims as compared with control subjects. A decrease in protein expression of $\mathrm{RI} \alpha$ and $\mathrm{RI} \beta$ subunits was also found in the NA. However, no significant changes in either the PKA activity or protein and mRNA expression of any of the PKA subunits was observed in the hippocampus of teenage suicide victims as compared with control subjects.

Our observation that PKA activity and cAMP binding were reduced in the PFC of teenage suicide victims was similar to what we have observed in adult depressed suicide victims (Dwivedi et al, 2004). However, when we determined the protein and mRNA expression of PKA subunits, a different pattern emerged in the PFC of teenage suicide victims. Whereas we had observed that the protein and mRNA expression of RII $\beta$ and $\mathrm{C} \beta$ was decreased in both membrane as well as cytosol fractions of the PFC of adult depressed suicide victims, as compared with control subjects, we observed that, in contrast, the protein expression of $\mathrm{RI} \alpha$ and $\mathrm{RI} \beta$ was significantly decreased in the PFC of teenage suicide victims as compared with control subjects in both membrane as well as in cytosol fractions. That this decrease in the protein expression of $\mathrm{RI} \alpha$ and $\mathrm{RI} \beta$ occurs at the transcriptional level became evident when we found that the mRNA expression levels of RI $\alpha$ and $\mathrm{RI} \beta$ were also significantly decreased in the PFC of teenage suicide victims as compared with control subjects.

To examine if the changes were region specific, we determined the protein and mRNA expression of PKA subunits in the hippocampus and NA of teenage suicide victims and control subjects. We selected the hippocampus because abnormalities in the hippocampus have been implicated in affective disorders and it is a major site for the effect of stress (Sapolsky, 1996; McEwen, 1999), an important risk factor in suicide, and is also associated with cognition (Sweatt, 2004). We selected the NA since it has been shown to be involved not only in the reward system (Cardinal and Everitt, 2004) but also in depression (Eisch et al, 2003). We did not find any significant changes in PKA activity or in the protein or mRNA expression of any of the PKA subunits, either in membrane or cytosol fractions of the hippocampus obtained from teenage suicide victims as compared with control subjects. However, when we compared the protein and mRNA expression of PKA subunits in the NA between teenage suicide victims and controls, we found a similar pattern of changes in the protein levels of PKA subunits as was observed in the PFC, namely, that there was a significant decrease in the protein expression of both $\mathrm{RI} \alpha$ and $\mathrm{RI} \beta$ subunits in the membrane and cytosol fractions of the NA obtained from the teenage suicide victims. However, we observed that the mRNA expression levels of $\mathrm{RI} \alpha$, but not $\mathrm{RI} \beta$, were significantly decreased in the NA of suicide victims. The reason for this dissociation between the protein and mRNA expression levels of $\mathrm{RI} \beta$ in the NA is not clear but may be related to post-translational changes in the RI $\beta$ subunits.

Our observation of decreased PKA activity and decreased RI subunits in teenage suicide raises the following questions: (1) what may be the mechanism that causes changes in PKA activity and (2) what may be the functional consequences. The major mechanism causing alterations in PKA activity and in its subunits is probably related to the 
adaptive changes in the cAMP signaling cascade in suicide. It has been shown that in rat sertoli cells, activation of the cAMP pathway stimulates mRNA levels of RI $\alpha$, RII $\alpha$, and RII $\beta$ (Oyen et al, 1988). The altered cAMP levels could result from changes either in number or function of receptors, such as $\beta_{2}$-adrenergic receptors, or from altered coupling of $\beta_{2}$ receptors with $\mathrm{G}$ protein. Changes in $\beta$ receptors and in $\mathrm{G}$ protein function have been reported in the adult suicide brain (Pacheco et al, 1996; Mann et al, 1986), and recently our group also reported that the protein expression of $\mathrm{G}$ proteins is altered in the post-mortem brain of teenage suicide victims (Dwivedi et al, 2002b). The other possibility that could cause changes in the cAMP signaling system and in the levels of cAMP in the teenage suicide brain may be related to alterations in the levels of PKC in these subjects. In a recent publication, our group showed a decrease in the protein and mRNA expression as well as in PKC activity in the post-mortem brain of teenage suicide victims. PKC could interact either with the neurotransmitter receptors linked to the cAMP system or with $G$ protein to cause changes in the levels of cAMP.

Abnormalities in PKA have been reported in the postmortem brain of bipolar subjects and in platelets and/or fibroblasts of depressed and bipolar patients. Fields et al (1999) found increased catalytic activity of PKA, whereas Rahman et al (1997) reported lower $\left[{ }^{3} \mathrm{H}\right] \mathrm{cAMP}$ binding in the post-mortem brain of bipolar patients. Chang et al (2003) showed increased protein levels of $\mathrm{C} \alpha$ and $\operatorname{RII} \beta$ in the same bipolar patients. In general, a decrease in $\left[{ }^{3} \mathrm{H}\right]$ cAMP binding and in PKA activity in depression has been reported (Shelton et al, 1996; Manier et al, 1996), although a recent study suggests no change in cAMP-stimulated PKA activity in occipital cortex of deprssed sucide victims (Hsiung et al, 2003). These findings do indicate alterations in PKA in depression and bipolar illness. Our study, although not comparable to the others since they were not conducted in suicidal subjects, is nonetheless consistent, showing abnormalities not only in PKA activity and $\left[{ }^{3} \mathrm{H}\right] \mathrm{cAMP}$ binding but also in protein and mRNA expression of specific subunits of PKA.

The other question is the functional consequences of the altered $\mathrm{R}$ subunits in the teenage suicide brain. It has been shown that one of the functions of the regulatory subunits is to protect the catalytic subunits from proteolytic degradation by binding and keeping them in the holoenzyme state (Brandon et al, 1995, 1998). A decrease or an increase in any of the $\mathrm{R}$ subunits may thus result in a proteolytic degradation of $\mathrm{C}$ subunits and hence a decrease in PKA activity. However, there are some interesting regulatory properties of the subunits. In RII $\beta$ mutant mice, the level of $\mathrm{RI} \alpha$ was found to be increased, and this compensatory increase minimizes the degradation of $\mathrm{C}$ subunits. However, in the brain tissue of RII $\beta$ mutant mice, there does not appear to be compensation by RI subunits, and hence there is a decrease in the $\mathrm{C} \alpha$ and $\mathrm{C} \beta$ subunit levels, primarily because of the decrease in the RII $\beta$ subunits.

The other important observation of this teenage suicide brain study was that there were no changes either in PKA activity or in the protein and mRNA expression of any of the subunits of PKA in the hippocampus. The significance of this regional specificity of changes in PKA is unclear at this time. Both PFC and NA appear to be involved in emotion and depression, as well as the reward system; whereas the hippocampus appears to be associated much more with memory and cognition. Teenage suicide may be related more to an alteration in aggressive impulsive and emotional behavior rather than memory and cognition; however, this is only a speculation at this stage.

This study of PKA activity and its subunits in the teenage suicide brain has resulted in some important and interesting observations. It does show that the decrease in PKA activity in specific brain regions is probably related to a decrease in the RI subunits, causing a proteolytic degradation of the $\mathrm{C}$ subunits and subsequently a decrease in PKA activity. We have earlier shown a relationship between alterations in the RII $\beta$ and $C \beta$ subunits and PKA activity in adult depressed suicide victims. This is the first demonstration of alteration of PKA activity and specific PKA subunits in teenage suicide.

\section{ACKNOWLEDGEMENTS}

This work was supported by Grants RO1 MH 48153 (Dr Pandey) and KO1 MH 01836 and RO1 MH 068777 (Dr Dwivedi) from the National Institute of Mental Health, Rockville, MD; and from the American Foundation for Suicide Prevention (Dr Dwivedi), New York, NY. We thank Barbara Brown BS, and Miljana Petkovic BS, for their help in organizing the brain tissue.

\section{REFERENCES}

Apter A, Gothelf D, Orbach I, Weizman R, Ratzoni G, Har-Even D et al (1995). Correlation of suicidal and violent behavior in different diagnostic categories in hospitalized adolescent patients. J Am Acad Child Adolesc Psychiatry 34: 912-918.

Brandon EP, Logue SF, Adams MR, Qi M, Sullivan SP, Matsumoto AM et al (1998). Defective motor behavior and neural gene expression in RII $\beta$-protein kinase A mutant mice. J Neurosci 18: 3639-3649.

Brandon EP, Zhuo M, Huang YY, Qi M, Gerhold KA, Burton KA et al (1995). Hippocampal long-term depression and depotentiation are defective in mice carrying a targeted disruption of the gene encoding the RI beta subunit of cAMP-dependent protein kinase. Proc Natl Acad Sci USA 92: 8851-8855.

Brent D, Kolko D, Wartella M, Boylan M, Moritz G, Baugher M et al (1993). Adolescent psychiatric inpatients' risk of suicide attempt at 6-month follow-up. J Am Acad Child Adolesc Psychiatry 32: 95-105.

Cardinal RN, Everitt BJ (2004). Neural and psychological mechanisms underlying appetitive learning: links to drug addiction. Curr Opin Neurobiol 14: 156-162.

Chang A, Li PP, Warsh JJ (2003). Altered cAMP-dependent protein kinase A subunit immunolabeling in postmortem brain from patients with bipolar affective disorder. J. Neurochem 84: 781-791.

Dwivedi Y, Conley RR, Roberts RC, Tamminga CA, Pandey GN (2002a). [ $\left.{ }^{3} \mathrm{H}\right]$ cAMP binding sites and protein kinase A activity in the prefrontal cortex of suicide victims. Am J Psychiatry 159: 66-73.

Dwivedi Y, Rizavi HS, Conley RR, Roberts RC, Tamminga CA, Pandey GN (2002b). mRNA and protein expression of selective alpha subunits of $\mathrm{G}$ proteins are abnormal in prefrontal cortex of suicide victims. Neuropsychopharmacology 27: 499-517.

Dwivedi Y, Rizavi HS, Shukla PK, Lyons J, Faludi G, Palkovits M et al (2004). Protein kinase A in postmortem brain of depressed 
suicide victims: altered expression of specific regulatory and catalytic subunits. Biol Psychiatry 55: 234-243.

Eisch AJ, Bolanos CA, de Wit J, Simonak RD, Pudiak CM, Barrot M et al (2003). Brain-derived neurotrophic factor in the ventral midbrain-nucleus accumbens pathway: a role in depression. Biol Psychiatry 54: 994-1005.

Fields A, Li PP, Kish SJ, Warsh J (1999). Increased cyclic AMP-dependent protein kinase activity in postmortem brain from patients with bipolar affective disorder. J Neurochem 73: 1704-1710.

Fimia GM, Sassone-Corsi P (2001). Cyclic AMP signaling. J Cell Sci 114: 1971-1972.

Gross-Isseroff R, Biegon A, Voet H, Weizman A (1998). The suicide brain: a review of postmortem receptor/transporter binding studies. Neurosci Biobehav Rev 22: 653-661.

Hsiung SC, Adlersberg M, Arango V, Mann JJ, Tamir H, Liu KP (2003). Attenuated 5-HT1A receptor signaling in brains of suicide victims: involvement of adenylyl cyclase, phosphatidylinositol 3-kinase, Akt and mitogen-activated protein kinase. J Neurochem 87: 182-194.

Lowry OH, Rosebrough NJ, Farr AL, Randall RJ (1951). Protein measurement with folin phenol reagent. J Biol Chem 193: 265-275.

Manier DH, Eiring A, Shelton RC, Sulser F (1996). Betaadrenoceptor-linked protein kinase A (PKA) activity in human fibroblasts from normal subjects and from patients with major depression. Neuropsychopharmacology 15: 555-561.

Mann JJ, Stanley M, McBride PA, McEwen BS (1986). Increased serotonin $_{2}$ and $\beta$-adrenergic receptor binding in the frontal cortices of suicide victims. Arch Gen Psychiatry 43: 945-959.

McEwen BS (1999). Stress and hippocampal plasticity. Annu Rev Neurosci 22: 105-122.

McPherson GA (1985). Analysis of radioligand binding experiments: a collection of computer programs for the IBM PC. J Pharmacol Methods 14: 213-228.

Nestler EJ, Greengard P (1994). Protein phosphorylation and the regulation of neuronal function. In: Siegel GH, Albers RW, Agranoff BW, Molinoff P (eds). Basic Neurochemistry: Molecular, Cellular, and Medical Aspects. Little, Brown: Boston, MA. pp 449-474.
Oyen O, Sandberg M, Eskild W, Levy FO, Knutsen G, Beebe S et al (1988). Differential regulation of messenger ribonucleic acids for specific subunits of cyclic adenosine $3^{\prime} 5^{\prime}$-monophosphate (cAMP)-dependent protein kinase by cAMP in rat Sertoli cells. Endocrinology 122: 2658-2666.

Pacheco MA, Stockmeier C, Meltzer HY, Overholser JC, Dilley GE, Jope RS (1996). Alterations in phosphoinositide signaling and G protein levels in depressed suicide brain. Brain Res 723: 37-45.

Pandey GN, Dwivedi Y, Pandey SC, Teas SS, Conley RR, Roberts RC et al (1999). Low phosphoinositide-specific phospholipase C activity and expression of phospholipase $C \beta_{1}$ protein in the prefrontal cortex of teenage suicide subjects. Am J Psychiatr 156: 1895-1901.

Pandey GN, Dwivedi Y, Rizavi H, Roberts RC, Conley RR, Tamminga CA (2004). Decreased catalytic activity and expression of Protein kinase $\mathrm{C}$ isozymes in teenage suicide victims: A postmortem brain study. Arch Gen Psychiatry 61: 685-693.

Pandey GN, Dwivedi Y, Rizavi HS, Ren X, Pandey SC, Pesold C et al (2002). Higher expression of serotonin $(5 \mathrm{HT})_{2 \mathrm{~A}}$ receptors in the postmortem brain of teenage suicide victims. Am J Psychiatry 159: 419-429.

Rahman S, Li PP, Young LT, Kofman O, Kish SJ, Warsh JJ (1997). Reduced $\left[{ }^{3} \mathrm{H}\right]$ cyclic AMP binding in postmortem brain from subjects with bipolar affective disorder. J Neurochem 68: 297-304.

Sapolsky RM (1996). Stress, glucocorticoids, and damage to the nervous sytem: The current state of confusion. Stress 1: 1-19.

Shelton RC, Manier DH, Sulser F (1996). cAMP-dependent protein kinase activity in major depression. Am J Psychiatry 153: 1037-1042.

Skålhegg BS, Tasken K (2000). Specificity in the cAMP/PKA signaling pathway. Differential expression, regulation, and subcellular localization of subunits of PKA. Front Biosci 5: D678-D693.

Sweatt JD (2004). Hippocampal function in cognition. Psychopharmaocology (Berlin) 174: 99-110.

Tasken KA, Knutsen HK, Attramadal H, Tasken K, Jahnsen T, Hansson Eskid W (1991). Different mechanisms are involved in cAMP-mediated induction of mRNAs for subunits of cAMPdependent protein kinases. Mol Endocrinol 5: 21-28. 